\title{
Diethylstilbestrol Alters the Expression of Activins in the Neonatal Mouse Ovary In Vitro
}

\author{
SACHIYO OIKAWA ${ }^{1}$, SACHIYO KOBAYASHI ${ }^{2}$, SHINICHI MIYAGAWA ${ }^{3}$, TAISEN IGUCHI ${ }^{1}$ and TOMOMI SATO TO $^{1,2}$ \\ ${ }^{1}$ Graduate School of Nanobioscience, ${ }^{2}$ International College of Arts and \\ Sciences, Yokohama City University, Yokohama, Japan; \\ ${ }^{3}$ Department of Biological Science and Technology, Tokyo University of Science, Tokyo, Japan
}

\begin{abstract}
Background/Aim: Perinatal diethylstilbestrol (DES) treatment induces the polyovular follicle containing two or more oocytes in a follicle of mouse ovary through estrogen receptor (ER) $\beta$. The aim of the study was to investigate the direct effects of DES on the neonatal mouse ovary and the gene expression of activins. Materials and Methods: Ovaries from neonatal wild-type (WT) or ER $\beta$ - knockout (ER $\beta K O)$ mice were organcultured in a serum-free medium with or without DES, and polyovular follicle induction and expression of activin signaling related genes were examined. Results: The polyovular follicle and cyst incidence in DES-treated organ-cultured ovaries from WT mice, but not from ER $\beta K O$ mice, was significantly higher than that of control non-treated cultures. DES altered inhibin (Inh) a, Inhba and Inhbb expression in organ-cultured ovaries from C57BL/6J mice, while no change in Inha and an increase of Inhbb were observed by DES, in both WT and ER $\beta K O$ mice. Conclusion: Alterations in activin signaling are involved in the polyovular follicle induction by DES.
\end{abstract}

The synthetic estrogen, diethylstilbestrol (DES), had been prescribed for pregnant women from the 1940s to 1970s to prevent miscarriage, however, daughters born from DESexposed mothers developed vaginal clear cell carcinoma and other reproductive abnormalities (1). In mice, neonatal exposure to DES causes various abnormalities in female reproductive organs, skeletal tissue and muscle (2-4). In the ovary, several morphological changes are detected, including the absence of corpora lutea, hypertrophy of interstitial tissue, and the appearance of hemorrhagic cysts (5-7). The

This article is freely accessible online.

Correspondence to: Dr. Tomomi Sato, Graduate School of Nanobioscience, Yokohama City University, 22-2 Seto, Kanazawaku, Yokohama 236-0027, Japan. Tel: +81 457872394, Fax: +81 457872413,e-mail: tomomi@yokohama-cu.ac.jp

Key Words: Diethylstilbestrol, ovary, activin, estrogen receptor (ER) $\beta$. polyovular follicle, which contains two or more oocytes per follicle, was also induced in the ovaries of mice perinatally exposed to DES (8). Ovaries of newborn mice organcultured with serum-free medium containing $1 \mu \mathrm{g} / \mathrm{ml}$ DES for 5 days and then transplanted into ovariectomized host mice have polyovular follicles $(9,10)$. These data indicate that DES acts directly on the mouse ovary to induce polyovular follicles. Actions of estrogen are mediated by estrogen receptors (ERs), $\operatorname{ER} \alpha$ and $\operatorname{ER} \beta$. DES can bind to both $\operatorname{ER} \alpha$ and $\operatorname{ER} \beta$, and its affinity is higher than $17 \beta$ estradiol (E2) (11). Studies in ER $\alpha$ knockout (ER $\alpha \mathrm{KO}$ ) or $\mathrm{ER} \beta$ knockout $(\mathrm{ER} \beta \mathrm{KO})$ mice, have revealed that DES induces polyovular follicles through ER $\beta$ (12).

The critical time for polyovular follicle induction by DES is postnatal day 3 (13), suggesting that DES can affect ovarian folliculogenesis during the neonatal period and induce polyovular follicles. In rodents, folliculogenesis begins soon after birth. Follicles are not yet formed in the prenatal mouse ovary, which consists only of germ cell cysts and somatic cells (14). Germ cell cysts are cell clusters formed by proliferation of female germ cells (14). After birth, cyst breakdown, involving a series of events such as apoptosis of oocytes, remodeling of the basal membrane and infolding of pregranulosa cells occurs, and approximately two thirds of oocytes are lost by apoptosis (15). Oocytes in germ cell cysts undergo cell death, and somatic cells invade into the cysts, and oocytes are subsequently surrounded by an adequate number of pre-granulosa cells for initiation of the primordial follicle formation. Primordial follicles develop into primary follicles, which consist of an oocyte surrounded by cuboidal granulosa cells. Neonatal DES exposure significantly decreases oocyte apoptosis in ovaries of 2-day-old wild-type (WT) and C57BL/6J mice but not in the ovaries of ER $\beta$ KO mice (6), indicating that DES suppresses oocyte apoptosis via $\operatorname{ER} \beta$ and results in polyovular follicle induction. However, the effects of DES on ER $\beta \mathrm{KO}$ mouse ovaries in vitro are not clear.

Activin, a member of the TGF $\beta$ superfamily, and its functional antagonist inhibin were originally isolated from gonadal sources, based on their ability to stimulate (activin) or 
in vivo $33: 1095-1102(2019)$

Table I. Sequences of oligonucleotides used as primers for real-time RT-PCR

\begin{tabular}{lll}
\hline Gene & Forward sequence $\left(5^{\prime} \rightarrow 3^{\prime}\right)$ & Reverse sequence $\left(3^{\prime} \rightarrow 5^{\prime}\right)$ \\
\hline Inha & CTGCTCTCAATATCTCCTTCCAAGAG & CCATGGCAGTAGTGGAAGATGATGAA \\
Inhba & ATCATCACCTTTGCCGAGTCA & TTCTGCACGCTCCACTACTGA \\
Inhbb & CCATCCAGGCCTTGTTTGA & AGCTGTCACACTGCACATCCA \\
P $t$ pia & TCTTCTGGCGTGCTTCTTGAA & TCCGAGATGGAGTTGCAAGAT \\
\hline
\end{tabular}

suppress (inhibin) the synthesis and secretion of folliclestimulating hormone $(\mathrm{FSH})(16-18)$. Activin consists of a dimer of two $\beta$-subunits, $\beta A$ or $\beta B$, to form activin $A(\beta A \beta A)$, activin $\mathrm{B}(\beta \mathrm{B} \beta \mathrm{B})$, or activin $\mathrm{AB}(\beta \mathrm{A} \beta \mathrm{B})$, whereas inhibin is a heterodimer of a unique inhibin $\alpha$ (inh $\alpha$ ) with either of the two $\beta$-subunits to form inhibin A $(\alpha \beta A)$ or inhibin $B(\alpha \beta B)(19)$. Activin binding to its type II receptor leads to recruitment and the subsequent phosphorylation of its type I receptor (20). Inhibin suppresses activin signaling by binding to activin type II receptors via its $\beta$-subunits without stimulation of type I receptor phosphorylation (21). Betaglycan (the type III TGF $\beta$ receptor) binds to inhibin to facilitate antagonism of activin (22). During folliculogenesis, activin subunits and receptors are expressed in the germ cells and somatic cells of the neonatal mouse ovary (23). In addition, administration of recombinant human activin $\mathrm{A}$ increases the number of primordial follicles in neonatal mouse ovary (23), indicating that activin facilitates follicle formation during the neonatal period. DES suppresses activin signals and delays follicle formation and follicle development in vivo $(6,24)$, therefore, DES may affect folliculogenesis through activin signaling in the neonatal mouse ovary. DES also increases the expression of Inha in the neonatal ovary (6), and mice over expressing the Inha gene show polyovular follicles (25), suggesting that an increase of Inha may be involved in polyovular follicle induction. However, whether DES can increase Inha through ER $\beta$ in the neonatal mouse ovary has not yet been elucidated.

This study aimed to examine the effects of DES on polyovular follicle induction through ER $\beta$ in the neonatal ovary in vitro. Ovaries from 0 -day-old WT or ER $\beta$ KO mice were organ-cultured on collagen gels for 5 days with or without DES, and histological changes and the expression of activin-related genes were subsequently examined.

\section{Materials and Methods}

Animals. Wild-type (WT) and ER $\beta$ knockout (ER $\beta$ KO) mice (26), and C57BL/6J Jcl mice (C57BL/6J, CLEA Japan, Tokyo, Japan) were kept at $23^{\circ} \mathrm{C}$ with a $12 \mathrm{~h}$ light $/ 12 \mathrm{~h}$ dark cycle caused by artificial illumination (lights on 0800-2000). They were fed a commercial diet (MF, Oriental Yeast, Tokyo, Japan) and had tap water ad libitum. ER $\beta$ KO mice were obtained from Professor Pierre Chambon at Institut de Génétique et de Biologie Moléculaire et
Cellulaire and they were backcrossed to C57BL/6J mice for more than ten generations. Pup genotypes were determined by multiplex PCR and WT mice were used as a control for ER $\beta$ KO mice. The day of birth was regarded as day 0 of age. All animals were maintained in accordance with the NIH Guide for the Care and Use of Laboratory Animals, and all experiments were approved by the Institutional Animal Care Committee of the Yokohama City University (No. H-A-16-002).

Organ culture system. An organ culture system for neonatal ovary was performed according to previous reports $(9,10)$. Eight volumes of Cellmatix type I-A (Nitta Gelatin, Osaka, Japan) were mixed with 1 volume 10x Waymouth MB 752/1 medium (Sigma Chemical, St. Louis, MO, USA) and then 1 volume $0.34 \mathrm{~N} \mathrm{NaOH}$ was added to the mixture. This cold gelation mixture $(300 \mu \mathrm{l})$ was poured into the well of a 4-well plate and allowed to form a gel at $37^{\circ} \mathrm{C}$. Ovaries of 0-day-old C57BL/6J, WT and ER $\beta K O$ mice were dissected and placed on collagen gels. Since ER $\beta$ KO mice were a mixed C57BL6/129sv background, WT mice were regarded as the control for ER $\beta \mathrm{KO}$ mice. Ovaries were organ-cultured in a humidified incubator at $37^{\circ} \mathrm{C}$ and $5 \% \mathrm{CO}_{2}$ with a serum-free medium (SF) for 1, 2, 3, or 5 days. For SF, Dulbecco's modified Eagle's medium/ Ham's F-12 medium (Thermo Fisher Scientific, Waltham, MA, USA) containing 100 units of penicillin and $100 \mu \mathrm{g} / \mathrm{ml}$ streptomycin (Thermo Fisher Scientific) was supplemented with $10 \mu \mathrm{g} / \mathrm{ml}$ insulin (Sigma), $10 \mu \mathrm{g} / \mathrm{ml}$ transferrin (Sigma), $10 \mu \mathrm{g} / \mathrm{ml}$ epidermal growth factor (EGF, Sigma), $10 \mathrm{ng} / \mathrm{ml}$ cholera toxin (Sigma), and $5 \mathrm{mg} / \mathrm{ml}$ bovine serum albumin fraction V (BSA, Sigma). The medium contained $1 \mu \mathrm{g} / \mathrm{ml}$ diethylstilbestrol (DES, Sigma) or ethanol alone as a control. One ovary was organ-cultured with SF containing ethanol and the other was organ-cultured with SF containing DES from the same mouse. Ten $\mu l$ of medium was added to each ovary every other day or at day 3 . Ovaries cultured for 5 days were fixed in Bouin's solution overnight $(n=8-22)$, embedded in paraffin, serially sectioned at $6 \mu \mathrm{m}$ and stained with hematoxylin and eosin (HE). The numbers of follicles, cysts, primordial, primary and polyovular follicles per section of each ovary were counted in every 7 th section. A polyovular follicle was defined as a follicle which contained more than two oocytes surrounded by granulosa cells within the basement membrane.

Grafting. C57BL/6J mouse ovaries organ-cultured for 5 days with SF containing $1 \mu \mathrm{g} / \mathrm{ml}$ DES or ethanol, were transplanted under the renal capsule of 2- to 3-month-old C57BL/6J mice. At the time of grafting, all host mice were ovariectomized. Animals were sacrificed 20 days after grafting to harvest the grafted ovaries $(n=4-$ 9 host mice). Grafted ovaries were fixed in Bouin's solution overnight, embedded in paraffin, serially sectioned at $8 \mu \mathrm{m}$ and stained with HE. The numbers of follicles and polyovular follicles of each ovary were counted on every 13 th section. 

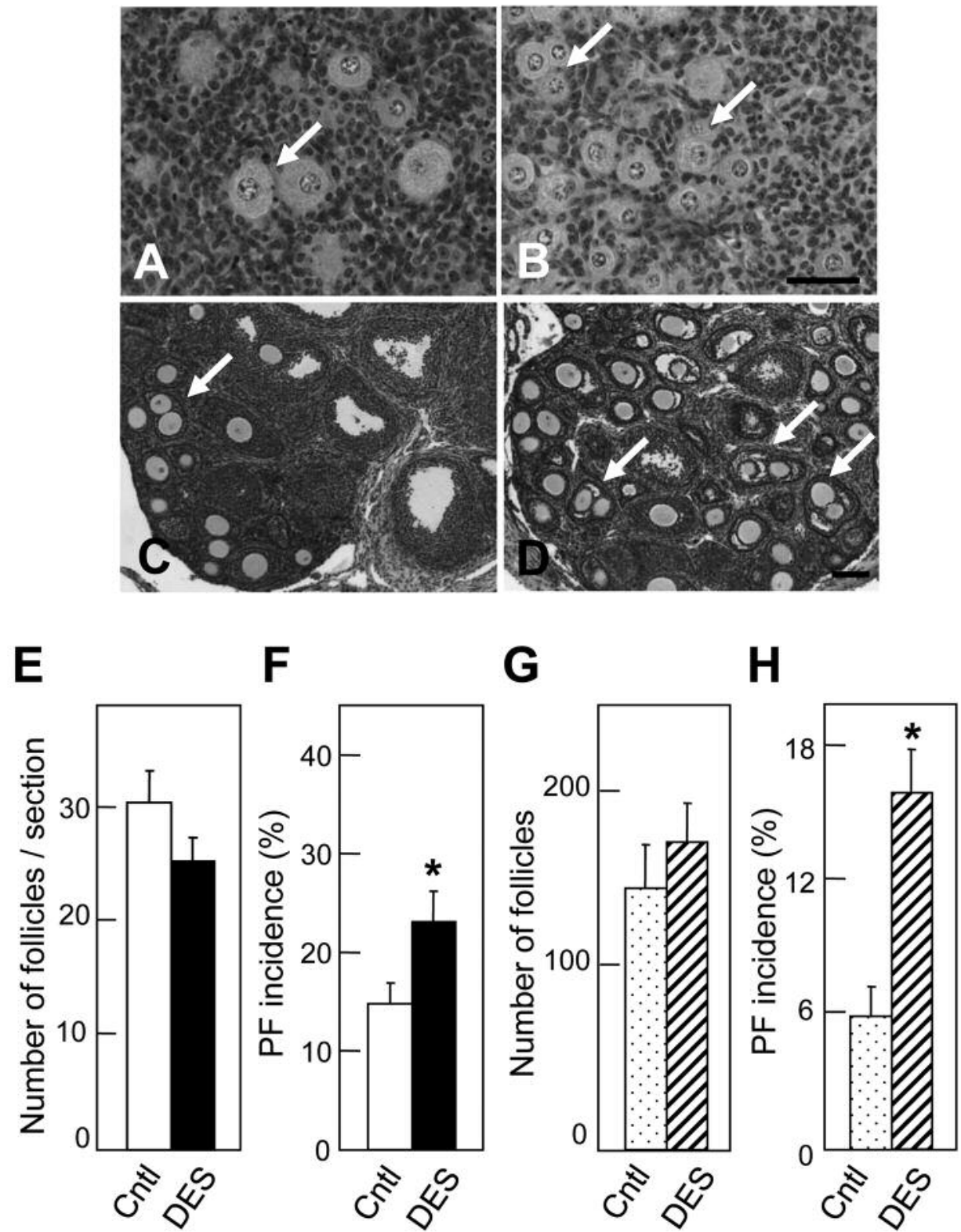

Figure 1. Ovaries organ-cultured with a serum-free medium (SF) containing ethanol (A) or $1 \mu \mathrm{g} / \mathrm{ml} D E S(B)$ for 5 days and grafted ovaries grown in vitro with $S F$ containing ethanol $(C)$ or $1 \mu \mathrm{g} / \mathrm{ml} D E S(D)$ for 5 days, respectively. Number of follicles per section $(E)$ and polyovular follicle incidence $(F)$ of organ-cultured ovaries with (DES) or without (control, Cntl) $1 \mu \mathrm{g} / \mathrm{ml}$ DES for 5 days. Number of follicles $(G)$ and polyovular follicle incidence $(H)$ of grafted ovaries grown in vitro with $(D E S)$ or without (Cntl) $1 \mu \mathrm{g} / \mathrm{ml}$ DES for 5 days. *p<0.05, compared with the Cntl group; White arrows=polyovular follicles; Scale bar in $B=100 \mu \mathrm{m}$; Scale bar in $D=200 \mu \mathrm{m}$.

RNA isolation and real-time RT-PCR. C57BL/6J, WT or ER $\beta \mathrm{KO}$ mouse ovaries organ-cultured for 5 days with or without $1 \mu \mathrm{g} / \mathrm{ml}$ DES were homogenized in TRIzol (Thermo Fisher Scientific) and total RNA was purified with a RNeasy total RNA kit (Qiagen, Hilden, Germany). Total RNA was reverse transcribed into cDNA using Super Script II reverse transcriptase (Thermo Fisher Scientific) with $0.05 \mathrm{mM}$ oligo (dT) primer (Thermo Fisher Scientific). Real-time RT-PCR was carried out using an Applied Biosystems StepOnePlus Real Time PCR System with Fast SYBR
Green Master Mix (Thermo Fisher Scientific). Relative mRNA expression of Inha, $\beta \mathrm{A}($ Inhba) subunit, $\beta \mathrm{B}(\operatorname{Inh} b b)$ subunit and follistatin ( $F$ st; Table I) was determined by the standard curve method. Peptidylprolyl isomerase A (Ppia) was chosen as an internal standard to control for variability in amplification due to differences in the starting mRNA concentrations. Melting-curve analysis showed a single peak for all samples. Organ-cultured ovaries of 10 mice were pooled for each point, and three independent experiments were carried out for each study. 
Follicle count and Statistical analysis. The numbers of total follicles, primordial follicles, primary follicles, cysts and polyovular follicles per section of each ovary were counted in every 7 th section. The data were analyzed by two-way analysis of Student's t-test after application of Levene's test for comparison of two mean values. For multiple comparisons, differences were estimated using ANOVA followed by Tukey HSD post-hoc test. Data were expressed as the mean \pm standard error. $p<0.05$ was considered to denote a statistically significant difference.

\section{Results}

Polyovular follicle induction in the neonatal mouse ovary in vitro. Many primordial and primary follicles were observed in organ-cultured ovaries with SF (Figure 1A and B), showing that follicles in ovaries organ-cultured with SF were well developed. The number of follicles per section was not changed by treatment with $1 \mu \mathrm{g} / \mathrm{ml}$ DES (Figure 1E), but the incidence of polyovular follicles was significantly increased in organ-cultured ovaries (Figure 1B and F).

Follicles at different stages, including secondary follicles and antral follicles, were observed in all grafted ovaries grown in vitro for 5 days (Figure $1 \mathrm{C}$ and $\mathrm{D}$ ). The number of total follicles was not changed by treatment with $1 \mu \mathrm{g} / \mathrm{ml}$ DES (Figure 1G), but polyovular follicles were frequently observed in grafted ovaries grown in vitro (Figure 1D). DES treatment significantly increased the polyovular follicle incidence of grafted ovaries grown in vitro (Figure $1 \mathrm{H}$ ).

Effects of DES on organ-cultured ovaries from 0-day-old WT and ER $\beta K O$ mice. To examine the involvement of ER $\beta$ in polyovular follicle induction by DES in vitro, ovaries from 0 -day-old WT and ER $\beta$ KO mice were organ-cultured in SF with or without $1 \mu \mathrm{g} / \mathrm{ml}$ DES and histological analysis was performed (Figure 2). Germ cell cysts, primordial, primary and polyovular follicles were found in ovaries of both WT and ER $\beta \mathrm{KO}$ mice organ-cultured in SF regardless of DES treatment (Figure 2). In ER $\beta \mathrm{KO}$ mouse ovaries organcultured in SF with or without DES, the numbers of primordial follicles and primary follicles per section were not changed compared with those in WT mouse ovaries (Figure 3A). In WT mouse ovaries organ-cultured in SF with DES treatment, the numbers of follicles and primordial follicles per section were significantly lower than those organcultured in SF without DES (Figure 3A). However, the number of primary follicles per section was not changed by DES treatment (Figure 3A). In ER $\beta \mathrm{KO}$ organ-cultured mouse ovaries, the numbers of follicles, primordial follicles and primary follicles per section were not changed by DES treatment (Figure 3A). In WT mouse ovaries organ-cultured in SF with DES, the incidences per section of polyovular follicles+cysts, cysts, and polyovular follicles were significantly increased compared with those in SF without DES treatment (Figure 3B). In contrast, the incidences of polyovular follicles+cysts, cysts, and polyovular follicles were not changed compared with those in control medium in organ-cultured ER $\beta$ KO mouse ovaries (Figure 3B).

Changes in mRNA expression of organ-cultured ovaries. In our previous report, neonatal DES exposure increased the percentage of primordial follicles and decreased the percentage of primary follicles in 5-day-old C57BL/6J mice, but not in WT mice (27). Therefore, gene expression was examined in the organ-cultured ovaries of C57BL/6J, WT and ER $\beta \mathrm{KO}$ mice. The mRNA expression of Inha, Inhba and Inhbb subunits and Fst was determined by real-time RT-PCR in organ-cultured C57BL/6J, WT and ER 3 KO mouse ovaries with or without 1 $\mu \mathrm{g} / \mathrm{ml}$ DES treatment. DES significantly increased Inha and Inhbb expression in organ-cultured ovaries, while the expression of Inhba was significantly decreased and Fst remained unchanged (Figure 4). In WT mouse organ-cultured ovaries, the expression of Inha tended to increase by DES, however, it was not changed in ER $\beta \mathrm{KO}$ mouse organ-cultured ovaries (Figure 4). The expression of Inhbb was significantly increased by DES treatment both in WT and ERßKO mouse organ-cultured ovaries (Figure 4). The expression of Fst was significantly decreased by DES in WT mouse organ-cultured ovaries, while it was increased in the absence of DES in ER $\beta$ KO mouse organ-cultured ovaries (Figure 4).

\section{Discussion}

Reduced estrogen and progesterone levels at birth may be a primary signal to initiate cyst breakdown (28). Polyovular follicles are induced in the ovaries of mice exposed perinatally to DES (8), therefore, impaired folliculogenesis may result in polyovular follicle induction. In this study, we used an organ culture system to examine the effects of DES on gene expression via ER $\beta$. Follicles in ovaries organcultured with SF were well developed and addition of DES significantly increased the polyovular follicle incidence both in organ-cultured and grafted ovaries that had been cultured in vitro $(9,10)$. Similarly, DES significantly increased the polyovular follicle incidence both in organ-cultured and grafted ovaries in this study.

Our previous report showed that the percentage of primary follicles in the ovaries of neonatally DES-treated WT and ER $\beta$ KO mice was not changed compared with that of oiltreated control mice (27). In this study, the number of primary follicles per section in WT and ER $\beta \mathrm{KO}$ mouse ovaries organcultured in SF was not changed by DES. Thus, DES treatment cannot inhibit the development of follicles from the primordial follicle stage to the primary follicle both in vivo and in vitro regardless of ER $\beta$. The polyovular follicle and cyst incidence per section in WT mouse ovaries organ-cultured in SF with DES was significantly higher than that in control medium, whereas it was not changed in organ-cultured ER $\beta \mathrm{KO}$ mouse 

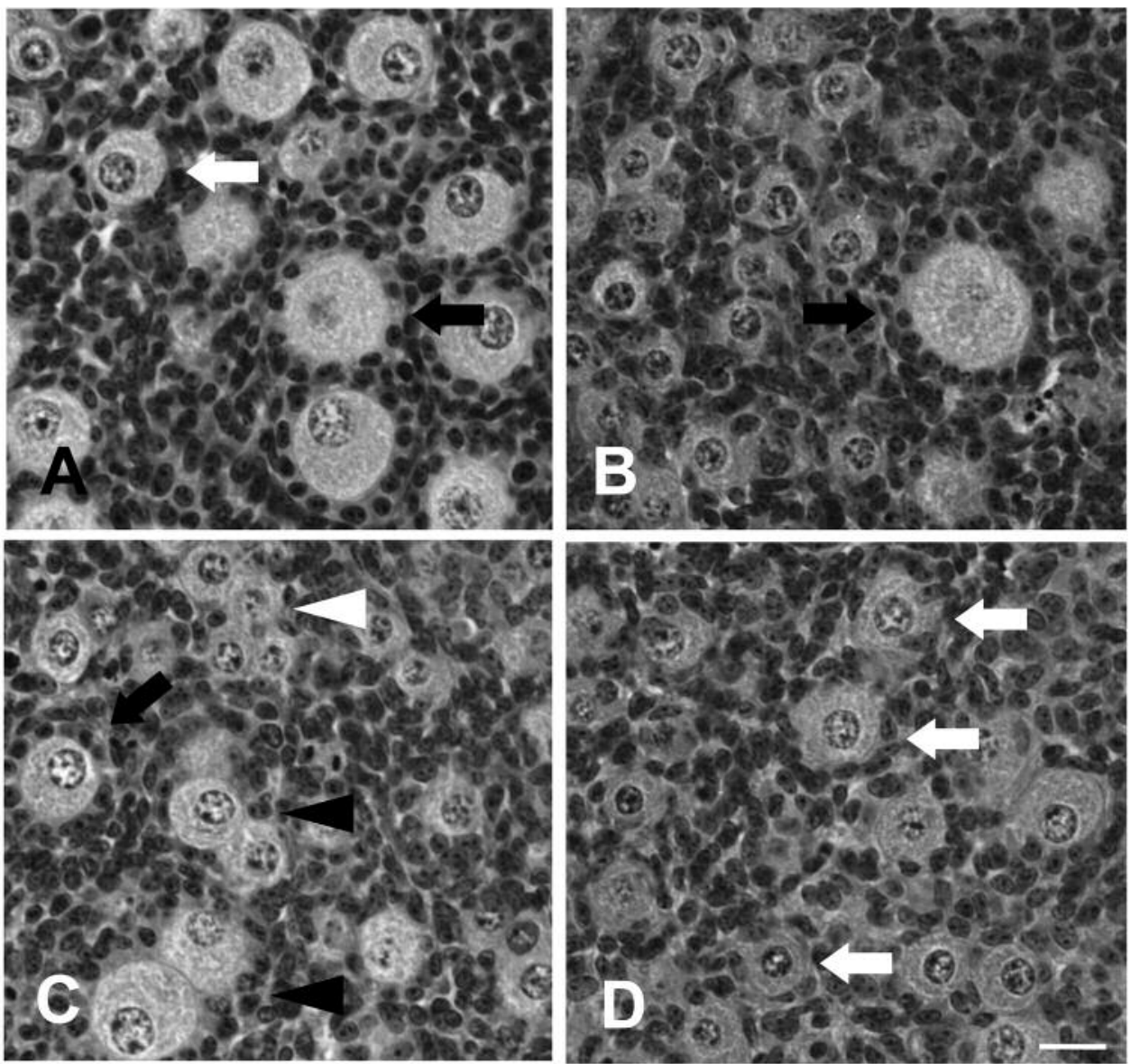

Figure 2. Histology of organ-cultured ovaries from 0-day-old wild-type (WT) (A and C) and ER $\beta$ knockout (ER $\beta K O, B$ and D) mice in SF with $1 \mu \mathrm{g} / \mathrm{ml}$ $D E S(C$ and $D)$ or ethanol alone ( $A$ and $B)$ for 5 days. White arrowheads indicate a cyst, black arrowheads indicate polyovular follicles, white arrows indicate primordial follicles and black arrows indicate primary follicles. Scale bar $=20 \mu \mathrm{m}$.

ovaries. These results suggest that DES can induce polyovular follicles through ovarian ER $\beta$ directly.

Neonatal DES exposure increases the expression of Inha in the ovary (6), however, the roles of inhibin on polyovular follicle induction are not clear. The expression of Inha and $I n h b b$ was increased whereas the expression of Inhba was decreased by DES treatment in organ-cultured ovaries, similar to changes in the ovaries of neonatally DES-treated mice (6). This fact suggests that DES directly alters activin signaling in the ovary. In addition, DES altered Inha, Inhba and Inhbb expression in organ-cultured ovaries of C57BL/6J mice. No change of Inha and an increase of Inhbb by DES were observed in organ-cultured ovaries of ER $\beta \mathrm{KO}$ mice. In WT mouse ovaries, the expression of Inha tended to increase by DES, but this increase was not statistically significant. Thus, the expression of Inha could be affected by DES through ER $\beta$. Changes in numbers of primordial and primary follicles are induced by DES in C57BL mice at 5 days of age, but not in WT mice (27), suggesting that the response of WT mouse ovaries to DES is not exactly the same as that of C57BL mouse ovaries. The incidence of polyovular follicles is different among the mouse strains (29), therefore, changes in the gene expression after DES treatment may be different in each mouse strain.

The expression of Inha and Inhba was relatively high, but Inhbb was low in vitro as well as in vivo (data not shown), indicating that activin A and inhibin A may be dominant in the neonatal ovary. An increase of Inhbb can alter the ratio of activin A and B, and inhibin A and B following DES treatment. Since activin A increases the number of primordial follicles in the neonatal mouse ovary (22), it is possible that DES treatment can suppress follicle formation through the inhibition of activin A signaling. In addition, an increase of Inhbb by DES treatment in organ-cultured ovaries may also result in an increase of activin $\mathrm{B}$ and activin $\mathrm{AB}$. Activin $\mathrm{B}$ increases both the expression of Inha and Inhba in vitro in the isolated secondary follicles from the immature mouse ovary, however, activin B does not stimulate follicle growth 

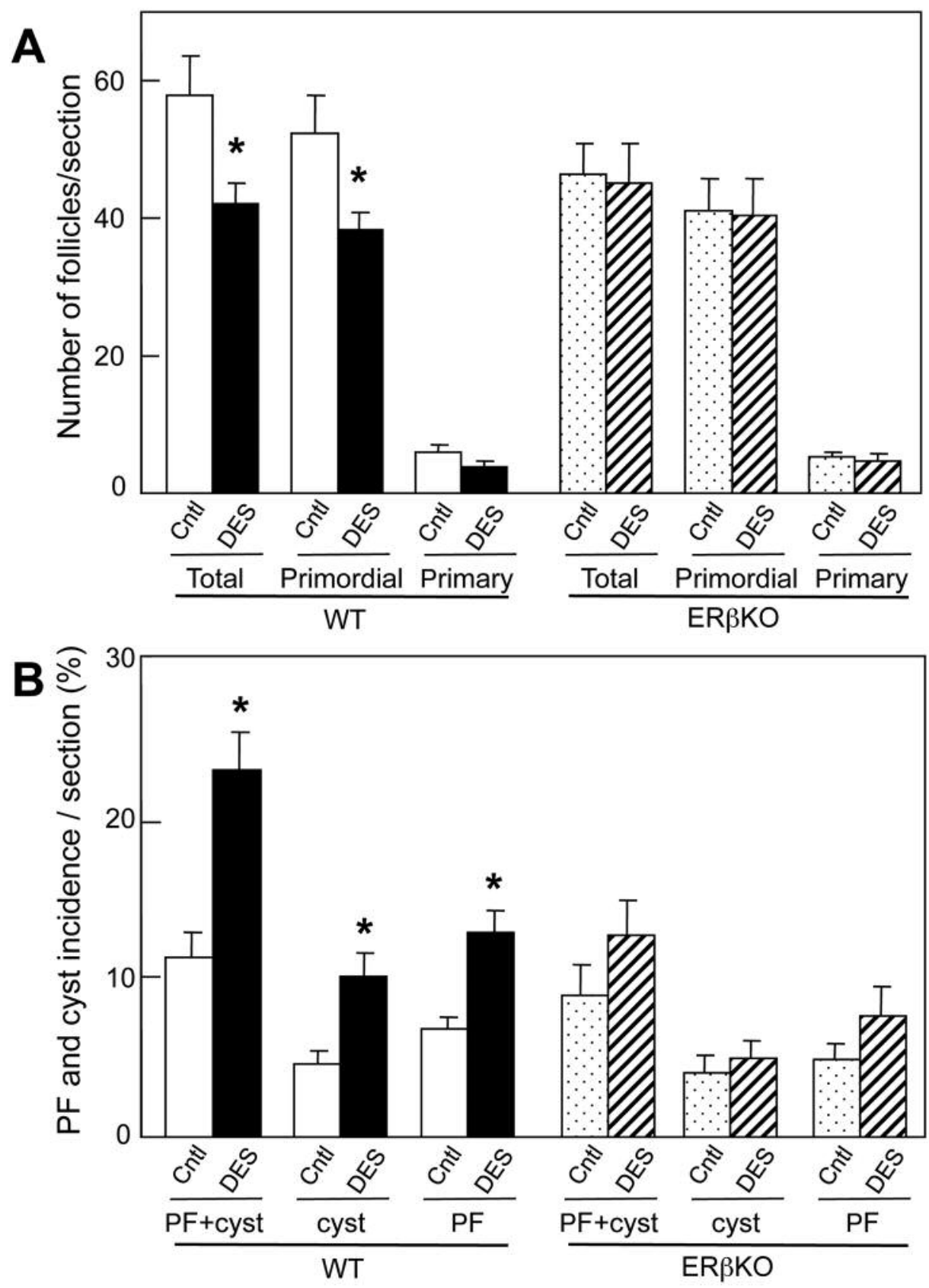

Figure 3. The numbers of total follicles, primordial follicles and primary follicles per section of organ-cultured ovaries from 0-day-old WT and ERßKO mice in SF with (DES) or without (Cntl) $1 \mu \mathrm{g} / \mathrm{ml}$ DES for 5 days (A). The incidence of polyovular follicles+cysts, cysts and polyovular follicles per section of organ-cultured ovaries from 0-day-old WT and ER $\beta K O$ mice in SF with (DES) or without (Cntl) $1 \mu \mathrm{g} / \mathrm{ml}$ DES for 5 days (B). * $p<0.05$, compared with Cntl group.

(30). Indeed, the numbers of total and primordial follicles were reduced by DES treatment in the organ-cultured ovary of WT mice, but not in ERßKO mouse ovaries. Since the number of follicles in organ-cultured ovaries was less than that in 5-day-old mouse ovaries regardless of DES treatment (6), the effects of DES on follicle numbers may not be evident. Kipp et al. (24) have shown that DES treatment suppresses both Inhba and Inhbb expression and reduces follicle numbers in ovaries at days 6 and 19. In immature rat granulosa cells, $10 \mu \mathrm{M}$ E2 increases the expression of Inha and Inhbb, whereas Inhba is not altered (31), similar to our results. Thus, the effects of estrogens on activin signaling in 

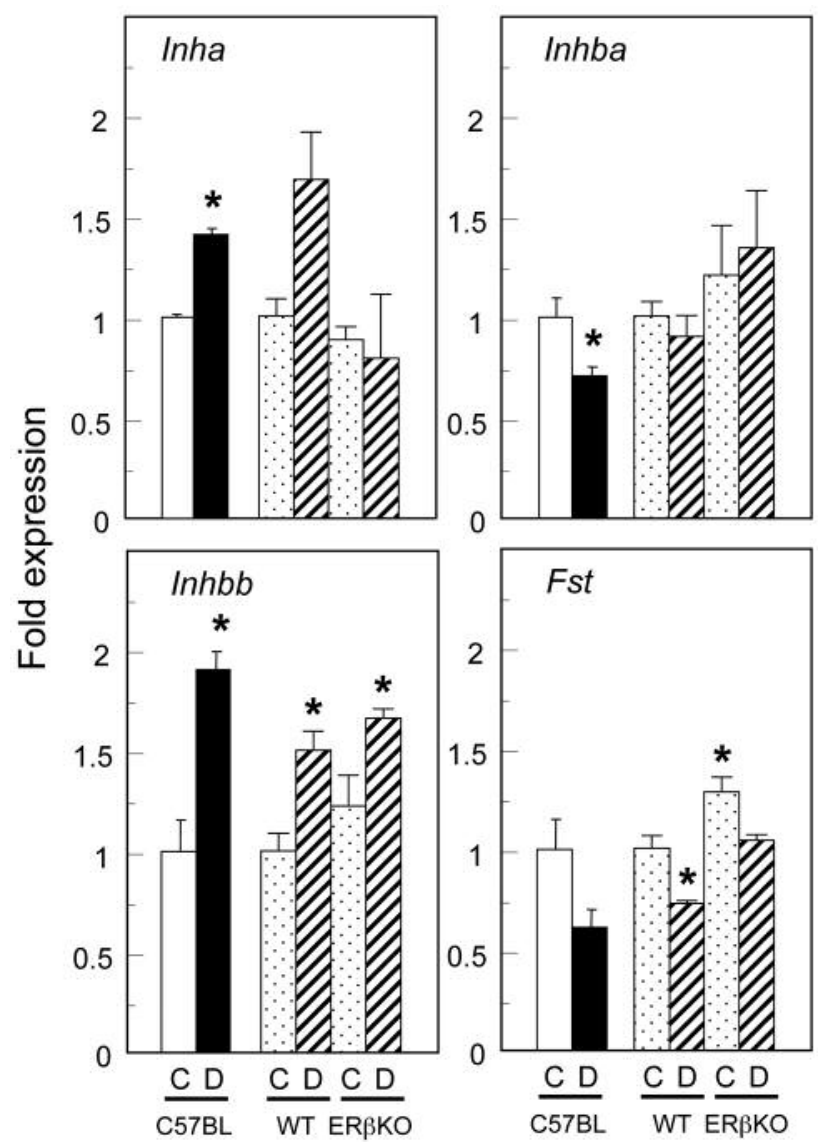

The expression of Inha could be affected by DES through $\mathrm{ER} \beta$, whereas that of $\operatorname{Inhbb}$ was not. Alterations in activin signaling, as well as other events during cyst breakdown, may be involved with polyovular follicle induction and suppression of follicle formation by DES.

\section{Conflicts of Interest}

There are no conflicts of interest regarding this study.

\section{Acknowledgements}

The Authors would like to thank Dr. Raphael Guzman, Department of Molecular Cell Biology and Cancer Research Laboratory of University of California at Berkeley, for his critical reading of this manuscript.

\section{Funding}

This work was partially supported by Grants for Support of the Promotion of Research at Yokohama City University (No. K17030 and W18005, to T.S.), a Grant-in-Aid for Scientific Research (B) (T.I.) and (C) (T.S.), and a Grant for Support of the Collaborative Study at NIBB (T.S).

\section{Authors' Contributions}

SO, SK and TS designed and performed research; SO, SK and TS analyzed data; SM provided ER $\beta$ knockout mice; SO, SK TI and TS wrote the paper.

Figure 4. The expression of Inhibin a (Inha), Inhba, Inhbb and follistatin (Fst) in organ-cultured ovaries of C57BL/6J (C57BL), WT and ERßKO mice with $1 \mu \mathrm{g} / \mathrm{ml}$ DES (D) or without DES $(C)$. Peptidylprolyl isomerase A was chosen as an internal standard. Data were expressed relative to $m R N A$ expression of organ-cultured $C 57 B L$ or WT mouse ovaries in $S F$ for 5 days $(=1.0)$. ${ }^{*} p<0.05$, compared to C57BL or WT C group.

the ovary may be different by age and estrogenic potency.

Administration of recombinant human activin A does not alter oocyte apoptosis but increases both granulosa and germ cell proliferation, resulting in an increase of the number of primordial follicles (23). Activin A increases preantral follicle diameters in immature mice, but not in adult mice (32). In the fetal mouse ovary, FSH stimulates primordial follicle formation accompanied with pre-granulosa cell proliferation and an increase of Inhba (33). These results suggest that activins play important roles in folliculogenesis through the regulation of somatic cell proliferation. Thus, dysregulation of the gene expression of each subunit may affect primordial follicle formation. Further study is needed to clarify the actions of activins and inhibins in polyovular follicle induction.

In conclusion, DES can directly induce polyovular follicles through the ovarian $\mathrm{ER} \beta$ in vitro as well as in vivo.

\section{References}

1 Herbst AL, Ulfelder H and Poskanzer DC: Adenocarcinoma of the vagina. N Engl J Med 284: 878-881, 1971. PMID: 5549830.

2 Takasugi N: Vaginal cornification in persistent-estrous mice. Endocrinology 72: 607-619, 1963. PMID: 13984603.

3 Iguchi T: Cellular effects of early exposure to sex hormones and antihormones. Int Rev Cytol 139: 1-57, 1992. PMID: 1428674.

4 Iguchi $\mathrm{T}$ and Sato T: Endocrine disruption and developmental abnormalities of female reproduction. Am Zool 40: 402-411, 2000.

5 Tenenbaum A and Forsberg JG: Structural and functional changes in ovaries from adult mice treated with diethylstilboestrol in the neonatal period. J Reprod Fertil 73: 465-477, 1985. PMID: 4039364.

6 Kim H, Nakajima T, Hayashi S, Chambon P, Watanabe H, Iguchi $\mathrm{T}$ and Sato T: Effects of diethylstilbestrol on programmed oocyte death and induction of polyovular follicles in neonatal mouse ovaries. Biol Reprod 81: 1002-1009, 2009. PMID: 19553606. DOI: $10.1095 /$ biolreprod.108.070599

7 Kakuta H, Tanaka M, Chambon P, Watanabe H, Iguchi T and Sato $\mathrm{T}$ : Involvement of gonadotropins in the induction of hypertrophyhyperplasia in the interstitial tissues of ovaries in neonatally diethylstilbestrol-treated mice. Reprod Toxicol 33: 35-44, 2012. PMID: 22100434. DOI: 10.1016/j.reprotox. 2011.10.013

8 Iguchi $\mathrm{T}$ and Takasugi N: Polyovular follicles in the ovary of immature mice exposed prenatally to diethylstilbestrol. Anat Embryol 175: 53-55, 1986. PMID: 3799991. 
9 Iguchi T, Fukazawa Y, Uesugi Y and Takasugi N: Polyovular follicles in mouse ovaries exposed neonatally to diethylstilbestrol in vivo and in vitro. Biol Reprod 43: 478-484, 1990. PMID: 2271729.

10 Terauchi KJ, Shigeta Y, Iguchi T and Sato T: Role of notch signaling in granulosa cell proliferation and polyovular follicle induction during folliculogenesis in mouse ovary. Cell Tissue Res 365: 197-208, 2016. PMID: 26899251. DOI: 10.1007/ s00441-016-2371-4

11 Kuiper GG, Carlsson B, Grandien K, Enmark E, Häggblad J, Nilsson S and Gustafsson JÅ: Comparison of the ligand binding specificity and transcript tissue distribution of estrogen receptors $\alpha$ and $\beta$. Endocrinology 138: 863-870, 1997. PMID: 9048584. DOI: $10.1210 /$ endo.138.3.4979

12 Kirigaya A, Kim H, Hayashi S, Chambon P, Watanabe H, Iguchi $\mathrm{T}$ and Sato $\mathrm{T}$ : Involvement of estrogen receptor $\beta$ in the induction of polyovular follicles in mouse ovaries exposed neonatally to diethylstilbestrol. Zool Sci 26: 704-712, 2009. PMID: 19832683. DOI: 10.2108/zsj.26.704

13 Iguchi T, Takasugi N, Bern HA and Mills KT: Frequent occurrence of polyovular follicles in ovaries of mice exposed neonatally to diethylstilbestrol. Teratology 34: 29-35, 1986. PMID: 3764775. DOI: 10.1002/tera.1420340105

14 Pepling ME and Spradling AC: Female mouse germ cells form synchronously dividing cysts. Development 125: 3323-3328, 1998. PMID: 9693136.

15 Pepling ME and Spradling AC: Mouse ovarian germ cell cysts undergo programmed breakdown to form primordial follicles. Dev Biol 234: 339-351, 2001. PMID: 11397004. DOI: 10.1006/ dbio.2001.0269

16 Ying SY, Czvik J, Becker A, Ling N, Ueno N and Guillemin R: Secretion of follicle-stimulating hormone and production of inhibin are reciprocally related. Proc Natl Acad Sci USA 84: 4631-4635, 1987. PMID: 3110772.

17 Schwall RH, Szonyi E, Mason AJ and Nikolics K: Activin stimulates secretion of follicle-stimulating hormone from pituitary cells desensitized to gonadotropin-releasing hormone. Biochem Biophys Res Commun 151: 1099-1104, 1988. PMID: 3128289.

18 Carroll RS, Kowash PM, Lofgren JA, Schwall RH and Chin WW: In vivo regulation of FSH synthesis by inhibin and activin. Endocrinology 129: 3299-3304, 1991. PMID: 1954905. DOI: 10.1210/endo-129-6-3299

19 Ying SY: Inhibins, activins, and follistatins: gonadal proteins modulating the secretion of follicle-stimulating hormone. Endocr Rev 9: 267-293, 1988. PMID: 3136011. DOI: 10.1210/edrv-92-267

20 Bernard DJ, Chapman SC and Woodruff TK: An emerging role for co-receptors in inhibin signal transduction. Mol Cell Endocrinol 180: 55-62, 2001. PMID: 11451572.

21 Martens JW, de Winter JP, Timmerman MA, McLuskey A, van Schaik RH, Themmen AP and de Jong FH: Inhibin interferes with activin signaling at the level of the activin receptor complex in Chinese hamster ovary cells. Endocrinology 138: 2928-2936, 1997. PMID: 9202237. DOI: 10.1210/endo.138.7.5250

22 Lewis KA, Gray PC, Blount AL, MacConell LA, Wiater E, Bilezikjian LM and Vale W: Betaglycan binds to inhibin and can mediate functional antagonism of activin signaling. Nature 404 : 411-414, 2000. PMID: 10746731. DOI: $10.1038 / 35006129$
23 Bristol-Gould SK, Kreeger PK, Selkirk CG, Kilen SM, Cook RW, Kipp JL, Shea LD, Mayo KE and Woodruff TK: Postnatal regulation of germ cells by activin: the establishment of the initial follicle pool. Dev Biol 298: 132-148, 2006. PMID: 16930587. DOI: 10.1016/j.ydbio.2006.06.025.

24 Kipp JL, Kilen SM, Bristol-Gould S, Woodruff TK and Mayo KE: Neonatal exposure to estrogens suppresses activin expression and signaling in the mouse ovary. Endocrinology 148: 1968-1976, 2007. PMID: 17255206. DOI: 10.1210/en. 2006-1083.

25 McMullen ML, Cho BN, Yates CJ and Mayo KE: Gonadal pathologies in transgenic mice expressing the rat inhibin $\alpha$ subunit. Endocrinology 142: 5005-5014, 2001. PMID: 11606469. DOI: 10.1210/endo.142.11.8472

26 Dupont S, Krust A, Gansmuller A, Dierich A, Chambon P and Mark M: Effect of single and compound knockouts of estrogen receptors $\alpha(E R \alpha)$ and $\beta(E R \beta)$ on mouse reproductive phenotypes. Development 127: 4277-4291, 2000. PMID: 10976058.

27 Kim H, Hayashi S, Chambon P, Watanabe H, Iguchi T and Sato T: Effects of diethylstilbestrol on ovarian follicle development in neonatal mice. Reprod Toxicol 27: 55-62, 2009. PMID: 19027844. DOI: $10.1016 /$ j.reprotox.2008.10.005

28 Chen Y, Jefferson WN, Newbold RR, Padilla-Banks E and Pepling ME: Estradiol, progesterone, and genistein inhibit oocyte nest breakdown and primordial follicle assembly in the neonatal mouse ovary in vitro and in vivo. Endocrinology 148: 3580-3590, 2007. PMID: 17446182. DOI: 10.1210/en.2007-0088

29 Iguchi T, Ohta Y, Fukazawa Y and Takasugi N: Strain differences in the induction of polyovular follicles by neonatal treatment with diethylstilbestrol in mice. Med Sci Res 15: 14071408, 1987.

30 Antenos M, Lei L, Xu M, Malipatil A, Kiesewetter S and Woodruff TK: Role of PCSK5 expression in mouse ovarian follicle development: identification of the inhibin $\alpha$ - and $\beta$ subunits as candidate substrates. PLoS One 6: e17348, 2011. PMID: 21408162. DOI: 10.1371/journal.pone.0017348

31 Turner IM, Saunders PT, Shimasaki S and Hillier SG: Regulation of inhibin subunit gene expression by FSH and estradiol in cultured rat granulosa cells. Endocrinology 125: 2790-2792, 1989. PMID: 2507299. DOI: 10.1210/endo-125-5-2790

32 Yokota H, Yamada K, Liu X, Kobayashi J, Abe Y, Mizunuma H and Ibuki Y: Paradoxical action of Activin A on folliculogenesis in immature and adult mice. Endocrinology 138: 4572-4576, 1997. PMID: 9348180. DOI: 10.1210/endo.138.11.5526

33 Lei L, Jin S, Mayo KE and Woodruff TK: The interactions between the stimulatory effect of follicle-stimulating hormone and the inhibitory effect of estrogen on mouse primordial folliculogenesis. Biol Reprod 82: 13-22, 2010. PMID: 19641178. DOI: $10.1095 /$ biolreprod.109.077404 